\title{
Micro-morphological Characterization of In-Vivo Diatoms Using ESEM
}

\author{
Eva Tihlaříková ${ }^{1}$, Vilém Neděla ${ }^{1}$ and Markéta Fránková ${ }^{2}$ \\ ${ }^{1 .}$ Environmental Electron Microscopy Group, Institute of Scientific Instruments of the CAS, Brno, \\ Czech Republic \\ 2. Laboratory of Paleoecology, Institute of Botany of the CAS, Brno, Czech Republic
}

Diatoms (Bacillariophyta) are one of the most distinctive and successful groups of unicellular photosynthetic algae [1]. They are ecologically widespread inhabiting mainly fresh, brackish and marine waters, often dominant in given microhabitats and contribute about one fourth to the world's productivity (in terms of carbon fixation) [2]. Diatoms are also the most species-rich algal group represented by $50-200$ thousand species. Diatom taxonomy is predominantly based on the morphology of ornate silicified cell wall called frustule which is composed of two overlapping parts (thecae). This frustule displays intricate patterns and designs unique to each species [3]. For these studies conventional scanning electron microscopy (SEM) was and still is widely used. This method requires cleaning of diatom frustules in strong acids and peroxides followed by conductive coating. This aggressive procedure removes protoplast and damages delicate structures. Environmental scanning electron microscopy (ESEM) brings advantages of observation of fresh diatom material that are presence of: 1) whole intact diatom cells, not only empty diatom frustules, 2) extracellular mucilaginous diatom secrets (e.g. pads, stalks, tubes), 3) whole diatom assemblages directly in situ together with other algal assemblages (e.g. cyanobacteria or green algae). However, in diatom research, ESEM is used mainly for elimination of conductive coating [4]. Observation of these aquatic organisms in their native wet state is not yet common even if it allows study of diatoms adhered directly on the host plant [5]. The ESEM observation of native aquatic samples is usually affected with radiation damage that can be lovered by the use of special methods like the Low Temperature Method for the ESEM (LTM) [6], ideally in a combination with advanced low noise detectors with very high detection efficiency.

Using the LTM we observed epiphytic diatom assemblages on a stem epidermis of common reed (Phragmites australis). Samples were observed using the FEI Peltier stage equipped with a special flat cylindrical brass sample holder. Epidermis was cut to $4-8 \mathrm{~mm}^{2}$ segments and placed into a drop of $2 \mu 1$ of water, to obtain better thermal contact between the sample and the Peltier stage. The observation conditions were adjusted according to [6]: the air pressure was $250 \mathrm{~Pa}$, sample temperature $-20^{\circ} \mathrm{C}$. All experiments were performed on FEI ESEM QUANTA 650FEG and carried out under constant operating conditions. The beam energy $20 \mathrm{kV}$, probe current $35 \mathrm{pA}$ and working distance was $8.5 \mathrm{~mm}$.

Traditional diatom taxonomy according to [7] based on the symmetry of a frustule distinguishes centric diatoms with radial symmetry (Figure $1 \mathrm{D}$ ) and pennate diatoms with bilateral symmetry (Figure $1 \mathrm{~A}, \mathrm{~B}$, C). Figures 1 A, B show a common benthic species Achnanthidium minutissimum able to attach to the surface with a gelatinous stalk. Both pictures show a frustule of this pennate diatom oriented up with its rapheless convex valve face ornamented with lines of pores called striae that are radially oriented around pseudoraphe. Figure $1 \mathrm{C}$ shows three individuals of the heteropolar genus Gomphonema attaching to the substrate with a mucilaginous stalk. Figure $1 \mathrm{D}$ shows a common planktic centric diatom Puncticulata balatonis known from mesotrophic and eutrophic European lakes and rivers with well visible radial striae at the marginal zone of the valve face and fultoportulae in the central area of the valve face. 
The work shows high applicable potential of the LTM ESEM to observe aquatic plants and algae under conditions of reduced gas pressure and low relative humidity with higher resolution as well as capability to observe susceptible structures like mucilaginous stalks that are destroyed during the preparation for SEM.

[1] D G Mann et al, The Chromophyte Algae: Problems and Perspectives 38 (1989), p. 307.

[2] D G Mann, Phycologia 38 (1999), p. 437.

[3] J Pickett-Heaps et al in "Progress in Phycological Research", ed. F E Round and D J Chapman, (Biopress Ltd., Bristol), p. 168.

[4] I L Norbäck et al, International Journal of Speleology 42 (3) (2013), p. 289.

[5] J John et al, Diatom Research 7(2) (1992), p. 403.

[6] V Neděla et al, Microscopy Research and Technique 78 (2015), p. 13.

[7] F E Round et al, Proc. R. Soc. Lond. B 211 (1981), p. 237.

[8] This study was supported by the research grant of the Ministry of Education, Youth and Sports in frame of the research program COST CZ, grant nr. LD 14045, by the Institute of Botany CAS as a longterm research development project no. RVO 67985939 and the NPUI LO1417 and LO1212 together with the European Commission (ALISI No. CZ.1.05/2.1.00/01.0017).
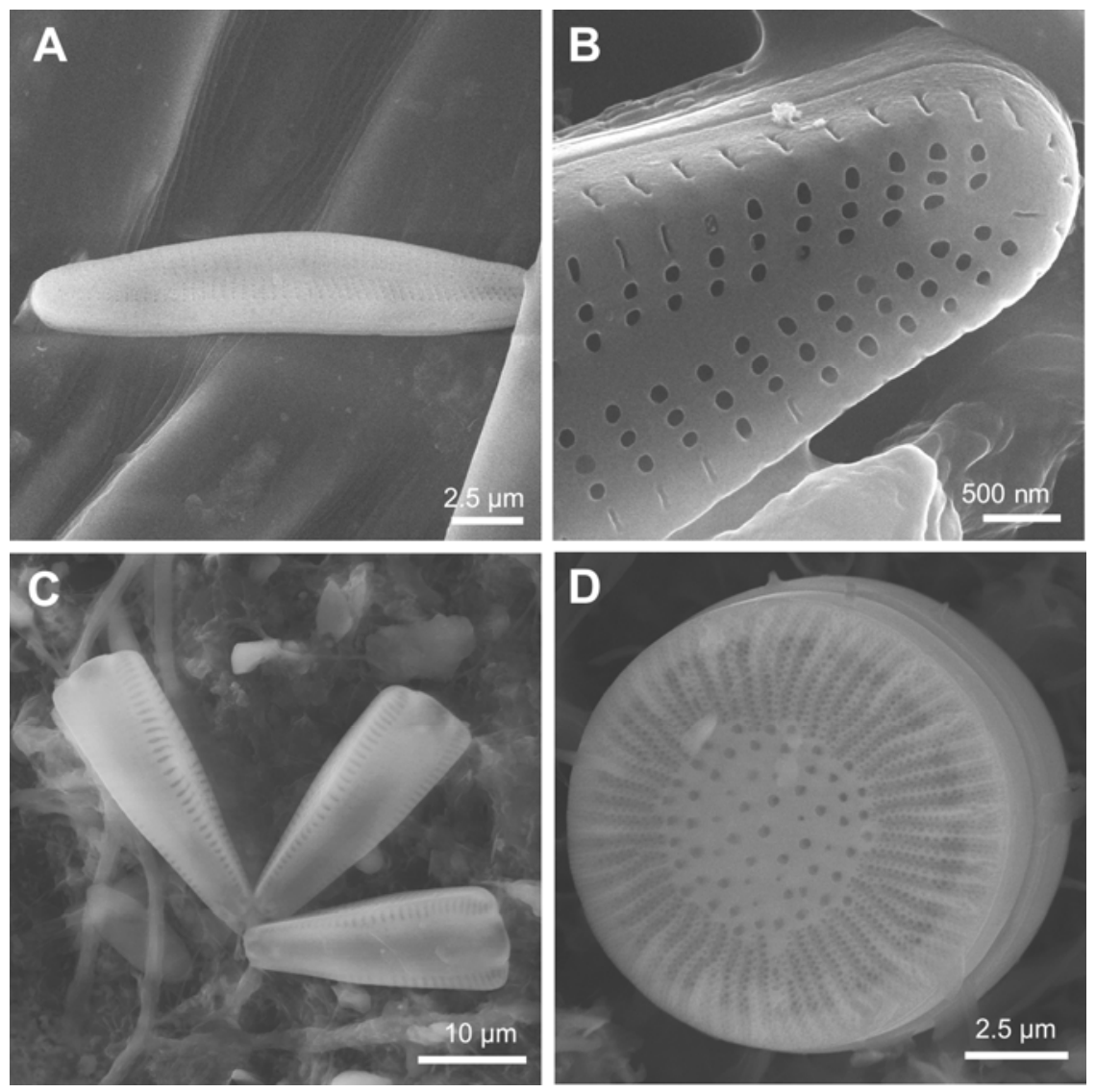

Figure 1. A) Benthic pennate diatom Achnanthidium minutissimum on a stem of common reed (Phragmites australis) B) Achnanthidium minutissimum - detail of valve end C) three individuals of a benthic pennate diatom Gomphonema sp. attached to the surface of common reed (Phragmites australis) with a mucilaginous stalk D) Planktic centric diatom Puncticulata balatonis. 